\title{
VALIDITY AND RELIABILITY OF A LITHUANIAN PHYSICAL EDUCATION TEACHERS' SELF-EFFICACY SCALE TOWARD INCLUSION OF STUDENTS WITH AUTISM SPECTRUM DISORDERS
}

\author{
Dovilė Selickaitė ${ }^{1}$, Yeshayahu Hutzler ${ }^{2}$, Kazimieras Pukėnas ${ }^{1}$, \\ Martin E. Block ${ }^{3}$, Diana Rèklaitienè ${ }^{1}$ \\ Lithuanian Sports University', Kaunas, Lithuania \\ Academic College at Wingate, Wingate Institute ${ }^{2}$, Netanya, Israel \\ Curry School of Education University of Virginia ${ }^{3}$, Charlottesville, VA, USA
}

\begin{abstract}
Background. Teacher's perceptions of Self-efficacy (SE) have been suggested as an important factor in the successful inclusion of students with special educational needs. The purposes of this study were (a) to investigate the validity and reliability of the instrument of physical education teachers' self-efficacy toward the inclusion of students with Autism Spectrum Disorders (PESEISD-A), using a Lithuanian physical education (PE) teachers' sample, and (b) to assess relationships between SE scale and subscales.

Methods. The English version of the instrument was translated into Lithuanian using the back-translation technique. The participants were $368 \mathrm{PE}$ teachers working in Lithuanian schools (152 males and 216 females), aged between 24 and 65 years $(M=47.09 ; S D=9.06)$. The content and construct validity of the instrument were supported.

Results. The results of the factor analysis indicated a one-factor solution for the scale's SE. Cronbach's alpha reliability of SE scale and all other subscales was high $(\alpha>.93)$. Test-retest correlation analysis showed a satisfactory coefficient. In this study, positive and significant relationships between SE scale, mastery experience, vicarious experience, social persuasion, physiological state, behaviour, and perceived challenges subscales were determined $(p<.01)$.

Conclusions. The Lithuanian version of the PESEISD-A appears to be a valid and reliable instrument, enabling future research on Lithuanian PE teachers.
\end{abstract}

Keywords: professional development, special education needs, self-efficacy theory, source of self-efficacy.

\section{INTRODUCTION}

$\mathrm{D}$ uring the last 25 years Lithuania has adopted a number of legal acts that oblige general education schools to implement the provisions of inclusive education. The consolidated text of the Law on Education of the Republic of Lithuania (Parliament of the Republic of Lithuania, 1991) of 2017 provides that the aim of the education of students with special educational needs (SEN) is to help the students to study according to their capacities, to get education and qualification, and to have their skills and potential recognized and developed. SEN was defined in Lithuania as the need for support and services in the process of education arising from the student's specific capacities, congenital or acquired disorders, and adverse effects from environmental agents (Parliament of the Republic of Lithuania, 1991). In Lithuanian general education schools, $11.92 \%$ of children aged 6-21 have SEN; $10.46 \%$ attend regular classes in mainstream schools, $0.34 \%$ of the children attend 
special education classes, and $1.12 \%$ of the children are educated in special schools or special education centres (Official Statistics Portal, 2018).

Some of the most rapidly growing populations of SEN are those with Autism Spectrum Disorder (ASD). The number of students with ASD included in mainstream classes has been steadily increasing over the last five years from 191 in 20132014 to 402 2017-2018 (Education Management Information System, 2018). Students with ASD have substantial impairments in social interaction and communication, which can challenge the general education teachers (Beamer and Yun, 2014). PE appears to be one of the most favourable disciplines, where values necessary for the effective development of inclusive education may be developed and maintained (Grenier, Dyson, \& Yeaton, 2005; Hutzler, 2007; André, Deneuve, \& Louvet, 2011; Klavina et al., 2014; Polvi \& Telama, 2000; Hutzler, 2003; Tubić, \& Đorđić, 2012; Qi, Wang, \& Ha, 2016). In this regard Zhang and Griffin (2007) have argued that encouraging students with ASD to interact with their peers should be considered a very important part of their physical education (PE) participation, and include basic social behaviours - such as taking turns in an activity, greeting peers, joining an activity, entering a game, sharing equipment, changing activities, or participating in an activity. Evidence is accumulating in support of including students with ASD in general physical education (GPE) classes and among the major research foci are factors affecting teachers' beliefs and behaviours (Beamer \& Yun, 2014; Buns, 2010; Morgan, 2013; Taliaferro \& Pilkington Harris, 2014; Yada \& Savolainen, 2017) or teachers' attitudes (Campos, 2013; Cassady, 2011; Combs, Elliott, \& Whipple, 2010; Hodge \& Jansma, 1999; Humphrey, \& Symes, 2013; Hutzler \& Levi, 2008; Tant, \& Watelain, 2016; Unianu, 2012). Meanwhile, not specific to $\mathrm{PE}$ teachers surveys performed in Lithuania indicated that the inclusion practice is challenged with barriers such as inadequate teacher training and lack of competence, lack of support, large class sizes, not enough preparation time due to administrative demands, and inadequate psychological training and support when working with children with SEN (Kiušaitė \& Dubauskaite, 2010; Paukštienè \& Ustilaite, 2012). These barriers are quite similar to those reported in other countries specifically for PE teachers (Baloun, Kudláček, Sklenaříková, Ješina, \& Migdauová, 2016; Block,
Hutzler, Barak, \& Klavina. 2013; Block, Kwon, \& Healy, 2016; Griggs \& Medcalf, 2015; Jerlinder, Danermark, \& Gill, 2010; Jeong \& Block, 2011; Ko \& Boswell, 2013; Kudláček, Baloun, \& Ješina, 2018; Tindall, Culhane, \& Foley, 2016). In a GPE class, the teacher has to create the environment for all, where personal weaknesses and disadvantages are not highlighted, where a student feels safe and as an equally important member of the community, and where measures are found to turn personal weaknesses and disadvantages into benefits and advantages in certain situations (Booth \& Ainscow, 2011; Ko \& Boswell, 2013). This can be achieved only by a teacher who is confident and who relies on the knowledge and its practical application at work (Block, Taliaferro, Harris, \& Krause, 2010; Griggs \& Medcalf, 2015). In order to create such an environment, the teacher must not only have knowledge but also have confidence in her/his skills and in the capability to apply this knowledge in various specific situations (Bandura, 1977, 1997). The way the teacher adapts the task, modifies the goal, applies educational methods and handles difficult situations depends on his or her level of situation and task-specific confidence. This has been labelled by Bandura $(1994,1997)$ as self-efficacy (SE), which is the confidence a person has in his or her own capability to produce desired levels of performance, relying on the knowledge and skill he or she possesses as compared to a social reference group. SE is a future-oriented belief about the level of competence a person expects he or she will display in a given situation (Tschannen-Moran \& Mcmaster, 2009). SE and goals are widely touted as two of the more important constructs in psychology and management (Vancouver, Thompson, \& Williams, 2001). Teachers' SE is their confidence and belief in being able to cater to the varied needs of all students in an inclusive school setting (Bandura, 1986, 2006; Block et al., 2010). Therefore, SE beliefs determine how environmental opportunities and impediments are perceived and affect the choice of activities, how much effort is expended on an activity, and how long people will persevere when confronting obstacles (Bandura, 2006). SE is the major unit in Bandura's (1986) Social Cognitive Learning Theory about the effect of an individual's interaction with others on his/her actions and behaviour and on the environment. SE theory, applied in the educational context, has sparked a rich line of research into how teachers' SE beliefs 
are related to their actions and to the outcomes they achieve (Tschannen-Moran \& Woolfolk Hoy, 2007). Furthermore, individual studies have found that teachers' SE is one of the strongest predictors of their attitudes towards inclusion (Block et al., 2010; Ilić-Stošović, Nikolić, \& Popadić, 2015; Karani, \& Skordilis, 2016). Stajkovic and Luthans' (1998) meta-analytical findings support a highly significant positive correlation between SE and work-related performance. Yada and Savolainen (2017) conclude that one way of changing teachers' attitudes is to improve their SE for inclusive practices and the results of their study indicate that more attention should be paid to teachers' lack of confidence regarding the inclusive practice. Fisher's (2017) study confirms the theoretical model's relationship between teacher perception of $\mathrm{SE}$ and teacher attitudes towards inclusion. A metaanalysis by Klassen and Tze (2014), consisting of 43 studies representing 9216 participants, demonstrated that teachers' perceived SE was related to increased persistence in working with challenging students; SE was shown to influence teachers' instructional practices, enthusiasm, commitment, and teaching behaviours. Given the pivotal role of SE beliefs in understanding human behaviour, it is important to understand how these beliefs are formed. Bandura $(1977,1986)$ suggested that SE beliefs are acquired and modified through four primary sources of information: mastery experiences, vicarious experiences, verbal/social persuasion, and physiological states. Also personal accomplishments (successes or failure) have the potential to exert the great influence on SE (Lent $\&$ Hackett, 2009). The success of psychological interventions can be enhanced by arranging experiences designed to strengthen SE beliefs for specific behaviours in specific problematic and challenging situations (Maddux, 2009). When people see themselves coping effectively with difficult situations, their sense of mastery is likely to be heightened (Maddux, 2009).

Given the current need for a supportive role of PE teachers toward inclusion, the exploration of PE teachers' SE and its links with demographics, the sources of SE, self-reported behaviours, and perceived challenges is needed for a better understanding of the pathways leading to enhancing students' with SEN inclusion. In order to facilitate this goal in Lithuania, an instrument that measures PE teachers' SE toward inclusion is needed, and its validity must be tested with a sample of local
PE teachers. A number of instruments have been created for the evaluation of general teachers' SE (Ilić-Stošović et al., 2015; Karbasi, \& Samani, 2016; Klassen \& Tze, 2014; Tschannen-Moran, Woolfolk Hoy, \& Hoy, 1998; Tschannen-Moran, \& Woolfolk Hoy, 2001; Sarı, Çeliköz, \& Seçer, 2009). According to the unique PE school framework, several specific instruments have been developed in this domain; SE in teaching PE under inclusive conditions (SEIPE) (Hutzler, Zach, \& Gafni, 2005) and the Physical Education Teaching Efficacy Scale (PETES) (Humphries, Hebert, Daigle, \& Martin, 2012) are generic instruments, while the Physical Educators' SE Toward Including Students with Disabilities-Autism (PESEISD-A, VERSION 8.2) (Beamer, \& Yun, 2014; Morgan, 2013; Li, Wang, Block, Sum, \& Wu, 2018; Taliaferro, 2010; Taliaferro, \& Pilkington Harris, 2014; Taliaferro, Hammond, \& Wyant, 2015) was designed to deal with one type of disability - that is ASD. The instrument consists of SE scale and six subscales (mastery experience, vicarious experience, social persuasion, behaviour, physiological states and challenges). Another instrument that was developed is situation- and disability-specific, and therefore may be useful for a variety of disability conditions and situations encountered during PE: the Situation Specific SE Instrument for Physical Education Teacher scale (SE-PETE-D) designed by Block and colleagues (2013). The SE-PETE-D has been adopted by both European and American scholars (Baloun et al., 2016; Eden \& Hutzler, 2015; Jovanović et al., 2014; Hutzler \& Shama, 2017; Kudláček, Baloun, \& Ješina, 2018; Reina, Hemmelmayr, \& Sierra-Marroquin, 2016; Taliaferro, Hammond, \& Wyant, 2015; Tekidou et al., 2015; Tindall et al., 2016).

This study top related with PE teachers' SE belief toward inclusion students with ASD, therefore we chose to validate PESEISD-A instrument. This instrument not only allows to identify PE teachers' SE toward including students with ASD but also to better understand the problems that cause the biggest difficulties for PE teachers to include pupils with ASD in a mainstream PE class, and understand the predictors that influence their SE and behaviour. The purpose of this study was (a) to investigate the validity and reliability of the instrument physical education teachers' self-efficacy toward the inclusion of students with Autism Spectrum Disorders (PESEISD-A), using a Lithuanian PE teachers' sample, and (b) to assess relationships between self-efficacy scale and subscales. 


\section{METHODS}

Participants. Our sample included a total of $368 \mathrm{PE}$ teachers from 30 municipalities who participated in the survey. Teachers' recruitment was conducted in January- March, 2017, using two modalities: (a) circulating the questionnaire by means of Email (Web-based), and (b) distributing a paper-based questionnaire to meetings with $\mathrm{PE}$ teachers in schools. Invitation letters to participate in the survey were sent to the Education Departments of all Lithuanian municipalities $(n=60)$. Twenty-eight Education Departments of Lithuanian municipalities returned confirmation letters indicating their agreement to cooperate and to send the survey information to the Emails of PE teachers in the department, and to encourage them to participate in the survey. According to the data from the year 2016 of the Lithuanian Centre of Information Technologies in Education, there were 1645 PE teachers working in these municipalities. However, only 49 PE teachers filled in the electronic survey, and additional 287 questionnaires were filled in during the meetings of PE teachers'. In order to fulfil the test-retest analysis, $22 \mathrm{PE}$ teachers from 12 schools located in two municipalities were additionally tested. The recruitment of these PE teachers was conducted using the distribution of a paper-based questionnaire.

The research design for implementing the study was approved by the Committee of Ethics of social science at the Lithuanian Sport University and from the Education Departments in the participating municipalities (No. SMTEK-09). The participants of the survey received and signed an informed consent form prior to filling in the questionnaires.

Instrument. Lithuanian version of instrument Physical Educators' Self-Efficacy toward Including Students with Disabilities - Autism (PESEISD-A; Taliaferro, Block, Harris, \& Krauske, 2011) was used for this study. The PESEISD-A was comprised of the SE scale and six subscales: mastery experience, vicarious experience, social persuasion, behaviour, physiological state and challenges. Demographic questions were included at the end of the instrument. Prior to filling in the questionnaires the interviewees were given the description of a person with ASD.

Self-efficacy. The scale is designed to evaluate PE teachers' SE in mainstreaming pupils with ASD in a general PE class and is called the Selfefficacy (SE) scale (10 questions). For the SE scale, participants were asked to rate their degree of confidence in their ability to perform each of ten tasks when including students with ASD in GPE classes: modify equipment, modify activities, create a safe environment, promote social interactions with peers, manage behaviours, modify instructions, assess motor sills, modify rules to games, collaborate effectively with other teachers/ professionals, and motivate students. Prior to filling in the questionnaires the interviewees were given the description of a person with ASD. Statements of the SE scale are scored in the range from 0 to 10 , with a score of 0 indicating the respondent (cannot do at all), a score of 5 indicating the respondent (moderately can do), and a score of 10 indicating the respondent is highly certain they can do).

Mastery experience. The first subscale is designed to evaluate PE teachers' mastery experiences, and is called the Mastery Experience (ME) subscale (10 questions). For the ME subscale, respondents rated the level of success they experienced in doing the same 10 identified tasks on a 5-point Likert scale of "not at all successful (Less than $15 \%$ of the time)" to "very successful (More than $85 \%$ of the time)", with the added option of "I do not have any experience doing this".

Vicarious experience. The second subscale is called the Vicarious Experience (VE) subscale (10 questions). For the VE subscale, respondents rated the level of success of other PE teachers they observed at performing the same ten identified tasks when including a child with ASD. Response choices were on a 5 point Likert scale ranging from "not at all successful (Less than $15 \%$ of the time" to "very successful (More than $85 \%$ of the time)", with the added option of indicating that they have not seen others perform the task.

Social persuasion. The third subscale is Social Persuasion (SP) subscale (10 questions) asked respondents to rate what others (teachers, parents, colleagues, supervisors, principals) have told them about their capabilities to include students with ASD in PE on a 5-point Likert scale of "not at all capable" to "very capable".

Behaviour. The fourth subscale is called the Behaviour (BEH) subscale (10 questions). For the BEH subscale, respondents rated how frequently they performed the ten identified teaching tasks on a 5-point Likert scale from "never" to "always",

Physiological state. The fifth subscale is called the Physiological State (PS) subscale (2 questions). The PS subscale asked participants to 
respond to two questions regarding how including a student with ASD in their PE class makes them feel (stressed or nervous). Responses were on a five point scale ranging from "definitely false" to "definitely true". Responses were reverse coded from one to five so that a higher score ("definitely false") reflected a more favourable reaction.

Perceived challenges. The sixth subscale the Perceived Challenges ( $\mathrm{PCH}$ ) subscale- asked participants to rate the extent to which each of 11 situations made it difficult to meaningfully include a student with ASD into their GPE program. The eleven situations included: "I am not sure how to modify activities", "I do not have time to make modifications", "I do not have appropriate equipment", "I have large class sizes", "there are multiple classes in the gym", "the students' skill level is very different than their peers", "I have no aid or support to help", "I do not have information about the student", "I have limited training on autism, the student has behavior problems, and the student has problems staying on task". Responses were on a 5-point Likert scale of "not at all an issue" to "very much an issue". Responses were coded from one to five such that the higher score indicated a higher degree of perceived challenge.

Demographic factors. In the instrument end, it covers demographic issues (age, gender, professional and personal experience of working with persons with ASD, etc.).

Scoring. The responses of on interviewee to the SE scale, ME, VE, SP, BEH, PS and PCH subscales statements were summed up and the average was calculated. A response of these subscales "I do not have any experience doing this" (ME), "I have not seen other PE teachers doing this" (VE), and "I have not been told anything about my capabilities" (SP) was coded as a zero. For example, if an individual responded "I do not have any experience doing this" (ME) to two items on the scale, their scores were summed and then divided by 8 (Taliaferro, 2010). The resulting score indicated the average success of the participants' mastery experiences. Respondents who answered "I do not have any experience doing this" across all 10 items were given a total score of 0 (Taliaferro, 2010). This did not reflect that the participant failed to respond to the subscale items. Instead, this indicated that the participant had no experience with the items in this subscale and was, therefore, unable to make a judgment regarding their level of success (Taliaferro, 2010).
Translation. The English version of the PESEISD-A (Taliaferro et al., 2011) instrument was translated into Lithuanian using the back translation technique described by Brislin (1986). This technique of translation requires four independent bilingual translators. Translator 1 and Translator 2 independently translated the original English version of the PESEISD-A questionnaire into Lithuanian. After comparing the translations, the translated instrument was forwarded to the other two bilingual translators who translated the instrument back into English. Finally, the retranslated version was compared with the original version by one of the authors of the original version for the final approval. In addition an expert review was performed. Two Lithuanian experts of adapted physical education were consulted about the clarity, conciseness and terminological precision of the Lithuanian version of the PESEISD-A. The initial version of the instrument was administered to a sample of $43 \mathrm{PE}$ teachers. This version confirmed its suitability for further analysis and was labelled PESEISD-A-LT.

Data analysis. SPSS Version 22.0 software was used to compute the statistical processes.

Construct validity. In order to establish the SE scale's factorial, structure and construct validity of the PESEISD-A-LT we chose to use an exploratory factor analysis (EFA). Based on Field's (2009) recommendations, an EFA was conducted using the principal component analysis (PCA) extraction method, followed by orthogonal (Varimax) rotation to maximize variance. Before conducting the PCA, statistical assumptions necessary for PCA were tested (Field, 2009). For example, the KaiserMeyer-Olkin (KMO) index should be greater than 0.70 and is considered inadequate if less than 0.50 (Field, 2009), and Bartlett's test of sphericity has to be highly significant $(p<.001)$ (Field, 2009). The optimal number of factors was determined by latent root criteria (eigenvalues $>1.0$, the Kaiser's criterion K1) and inspection of the scree plot (Field, 2009). An item with communality of less than 0.40 was removed from the analysis, and the PCA was computed again (Field, 2009).

Reliability analysis. Cronbach's alpha coefficient was employed to determine internal consistency, and test-retest reliability was employed to determine stability over time. Cronbach's $\alpha$ values of 0.70 and above imply an acceptable level of internal consistency (Bryman, 2015; Field, 2009). Test-retest reliability was used to examine stability 
among items in SE scale and each sub-scale. The period between the test-retest was 14 weeks. Testretest reliability was assessed by using SpearmanBrown's correlation. Following Vallerand (1989), we estimated that a coefficient of 0.6 or more for test retest is satisfactory.

Descriptives. Mean $(M)$, standard deviations $(S D)$, and frequency counts were used to characterize participants' demographics.

Spearman's rank correlation coefficient $(r)$ was used to discover the strength of the relationship between the SE scale and each subscale.

\section{RESULTS}

The total of $346 \mathrm{PE}$ teachers from 28 municipalities were included to the basic data analysis. Participants' age ranged from 24 to 65 years $(M=47.19 ; S D=9.04)$; gender distribution was 143 males $(M=46.04 ; S D=10.35)$ and 203 females $(M=48.09 ; S D=7.92)$. Participants had general PE teaching experience ranging from 1 to 45 years $(M=22.06 ; S D=9.86)$. Demographic information is illustrated in Table 1.
In order to fulfil the test-retest analysis, a group of nine males and 13 females, in total $22 \mathrm{PE}$ teachers, was formed. This group participants' mean age was 52.73 years $(S D=6.37$ years). These participants had a mean general PE teaching experience of 28.82 years $(S D=8.64$ years). Eighteen of these PE teachers reported having experience working with students with ASD in general PE in the last five years.

The EFA generated a one-factor solution accounting for $82.99 \%$ of the variance, the KMO measure verified the sampling adequacy for the analysis, exhibiting a KMO index of 0.941 and all $\mathrm{KMO}$ values for individual items $>0.90$. Bartlett's test of sphericity $\left(\chi^{2}[45]=5131.7, p<.001\right)$ indicated that correlations between items were sufficiently large for the PCA. An initial examination of the items using PCA revealed high communalities, and ranged from 0.74 to 0.88 . Cronbach's alpha measured internal consistency of the (sub)scales showed that all statements of the (sub)scales perfectly reflect the tested value (Table 2 ).

A repeated interview with the same respondents was done after 14 weeks to retest the stability of the (sub)scale. The Spearman-Brown correlation

\begin{tabular}{|c|c|c|}
\hline Demographic factors & $N$ & Percentage \\
\hline $\begin{array}{l}\text { Had undergraduate or graduate courses APE } \\
\text { Yes } \\
\text { No }\end{array}$ & $\begin{array}{c}73 \\
273\end{array}$ & $\begin{array}{l}21.10 \\
78.90\end{array}$ \\
\hline $\begin{array}{l}\text { Had undergraduate or graduate courses Special Education } \\
\text { Yes } \\
\text { No }\end{array}$ & $\begin{array}{l}176 \\
170\end{array}$ & $\begin{array}{l}50.90 \\
49.10\end{array}$ \\
\hline $\begin{array}{l}\text { Have been included students with ASD in PE class } \\
\text { Yes } \\
\text { No }\end{array}$ & $\begin{array}{l}166 \\
180\end{array}$ & $\begin{array}{l}48.00 \\
52.00\end{array}$ \\
\hline Have support from APE specialist & 40 & 11.60 \\
\hline Have support from Teacher assistants & 50 & 14.50 \\
\hline Have support from Special Education Teacher & 158 & 45.70 \\
\hline Have support from Physical therapist & 30 & 8.70 \\
\hline $\begin{array}{l}\text { Personal experiences with ASD } \\
\text { No experience } \\
\text { Yes }\end{array}$ & $\begin{array}{c}319 \\
27\end{array}$ & $\begin{array}{c}92.20 \\
7.80\end{array}$ \\
\hline $\begin{array}{l}\text { ME, VE \& SP } \\
\text { ME \&VE } \\
\text { ME \& SP } \\
\text { VE \&SP } \\
\text { ME only } \\
\text { VE only } \\
\text { SP only } \\
\text { ME, VE \& SP did not have }\end{array}$ & $\begin{array}{c}106 \\
25 \\
17 \\
4 \\
44 \\
21 \\
5 \\
124\end{array}$ & $\begin{array}{c}30.60 \\
4.90 \\
7.20 \\
1.20 \\
12.70 \\
6.10 \\
1.50 \\
35.80\end{array}$ \\
\hline Total 346 & & \\
\hline
\end{tabular}

Table 1. Demographic information of physical education teachers $(n=346)$

Note. APE - Adapted physical education; ASD - Autism Spectrum Disorder; PE - physical education; ME - mastery experience; VE - vicarious experience; SP - social persuasion; $N$ - number of physical education teachers. 
Table 2. Cronbach's Alpha values of PESEISDA-LT instrument SE scale and subscales $(n=$ 346)

\begin{tabular}{|l|c|c|c|c|}
\hline \multicolumn{1}{|c|}{ (Sub)scales } & N of Items & Mean & SD & Cronbach's Alpha \\
\hline Self-efficacy & 10 & 5.36 & 2.18 & .977 \\
\hline Mastery experience & 10 & 1.69 & 1.65 & .991 \\
\hline Vicarious experience & 10 & 1.35 & 1.63 & .994 \\
\hline Social persuasion & 10 & 1.33 & 1.81 & .996 \\
\hline Physiological state & 10 & 2.49 & 1.49 & .993 \\
\hline Behaviour & 2 & 2.97 & 1.17 & .932 \\
\hline Perceived challenges & 11 & 3.37 & 0.94 & .931 \\
\hline
\end{tabular}

Table 3. The Self-efficacy scale and subscales of the test-retest reliability $(n=22)$
Table 4. Inter-correlations of PESEISD-A (sub) scales

Note. SE - Self-efficacy; ME - mastery experience; $\mathrm{VE}$ - vicarious experience; $\mathrm{SP}$ - social persuasion; PS - physiological sate; $\mathrm{BEH}$ - behaviour; PCH perceived challenges; ${ }^{*}$ - correlation is significant at the .01 level.

\begin{tabular}{|l|c|c|c|}
\hline \multirow{2}{*}{\multicolumn{1}{c}{$($ Sub)scales }} & \multicolumn{2}{|c|}{ Cronbach's Alpha } & Spearman-Brown (Test-retest) \\
\cline { 2 - 4 } & 1 Time & 2 Time & $r$ \\
\hline Self-efficacy & .97 & .97 & .88 \\
\hline Mastery experience & .98 & .98 & .89 \\
\hline Vicarious experience & .99 & .99 & .85 \\
\hline Social persuasion & .98 & .99 & .87 \\
\hline Physiological state & .99 & .99 & .88 \\
\hline Behaviour & .79 & .74 & .81 \\
\hline Perceived challenges & .91 & .95 & .46 \\
\hline
\end{tabular}

\begin{tabular}{|l|c|c|c|c|c|c|c|}
\hline (Sub)Scale & SE & ME & VE & SP & PS & BEH & PCH \\
\hline SE & - & & & & & & \\
\hline ME & $.366^{*}$ & - & & & & & \\
\hline VE & $.282^{*}$ & $.574 *$ & - & & & & \\
\hline SP & $.271^{*}$ & $.616^{*}$ & $.600^{*}$ & - & & & \\
\hline PS & $-.300^{*}$ & $-.299^{*}$ & $-.186^{*}$ & $-.201^{*}$ & - & & \\
\hline BEH & $.296^{*}$ & $.796^{*}$ & $.580^{*}$ & $.628^{*}$ & $.292^{*}$ & - & \\
\hline PCH & $-.343^{*}$ & $-.312^{*}$ & $-.249^{*}$ & $-.269^{*}$ & $-.456^{*}$ & $-.315^{*}$ & - \\
\hline
\end{tabular}

coefficient of SE scale and subscales for assessing test-retest reliability was $>.80$, except perceived challenges subscale, which test-retest reliability coefficient was $r=.46$; correlation coefficients' of each subscale are shown in Table 3.

Correlation analysis indicated significant relationships between (sub)scales ( $p<.01$; Table 4$)$.

\section{DISCUSSION}

The first purpose of this study was to approve the Lithuanian version of the PESEISD-A validity and reliability.

The results of an exploratory factor analysis on the 10 question SE scale of the Lithuanian versions revealed a one-factor solution explaining 82.99 percent of the variance, while Taliaferro (2010) exploratory factor analysis revealed a one-factor solution explaining 57.05 percent of the variance, and $\mathrm{Li}$ et al. (2018) conducted Confirmatory Factor Analysis revealed the one-factor model of the PESEISD-A fit the total sample $(n=432)$ adequately. The coefficients of internal consistency and testretest reliability of PE teachers' self-efficacy toward including students with ASD into general PE classes scale, Mastery Experiences subscale, Vicarious Experiences subscale, Social Persuasion subscale, Physiological State subscale, and Behaviours subscale confirmed the appropriateness of the Lithuanian versions of PESEISD-A-LT for data analysis. However, when we analysed the testretest reliability of perceived challenges subscale 
we found lower than .6 correlation coefficient. This result shows that perceived challenges subscale is more sensitive to time period than other subscales. Perhaps it is related to a long time period between tests (14 weeks). When we compare our research results with those of Taliaferro's (2010) $(n=236)$ results, it can be observed that SE scale and all subscales validity and reliability coefficient values are similar or higher except for the coefficient of perceived challenges subscale test-retest scores, where the value was less than .60. A recently conducted study by Li et al. (2018) involving Chinese preservice physical educators $(n=432)$ showed high coefficients of internal consistency $(\alpha=.92)$ and testretest reliability $(r=.90)$ of SE scale.

The second purpose of this study was to assess relationship between self-efficacy scale and subscales. The correlation analysis between PEISEISD-A-LT (sub)scales showed that PE teachers' SE belief had strongest influence of mastery experience. According to Bandura (1995), the most influential source of efficacy information is personal mastery experiences because they provide the most authentic evidence of whether one can master whatever it takes to succeed in a particular field or endeavour. Tschannen-Moran and McMaster (2009) propose that SE beliefs may be diminished when success is achieved through extensive external assistance, after considerable effort, or on a task perceived as easy or unimportant. It serves to convince them that they have what it takes to achieve increasingly difficult accomplishments of a similar kind. Self-mastery is best achieved through progressive mastery, which is attained by breaking down difficult tasks into small steps that are relatively easy, in order to ensure a high level of initial success. Individuals should then be given progressively more difficult tasks in which constructive feedback is provided and accomplishments are celebrated before increasingly challenging tasks are attempted (Heslin \& Klehe, 2006). Also we found that source of efficacy information as vicarious experience, social persuasion, and physiological states are significant predictors on PE teachers' SE belief. The impact of modelling on beliefs of personal efficacy is strongly influenced by perceived similarity to the models (Bandura, 1986; Tschannen-Moran \& Mcmaster, 2009). Through their behaviour and expressed ways of thinking, competent models transmit knowledge and teach observers effective skills and strategies for managing environmental demands (Klassen \& Tze, 2014). People who are persuaded verbally that they possess the capabilities to master given activities are likely to mobilize greater effort and sustain it than if they harbour self-doubts and dwell on personal deficiencies when problems arise (Bandura, 1997; Tschannen-Moran $\&$ Mcmaster, 2009). To the extent that persuasive boosts in perceived SE lead people to try hard enough to succeed, self-affirming beliefs promote development of skills and a sense of personal efficacy. People also rely on their physiological and emotional states in judging their capabilities. They interpret their stress reactions and tension as signs of vulnerability to poor performance (Bandura, 1995). It is not the sheer intensity of emotional and physical reactions that is important but rather how they are perceived and interpreted (Bandura, 1995). For example, people who have a high sense of efficacy are likely to view their state of affective arousal as an energizing facilitator of performance, whereas those who are beset by self-doubts regard their arousal as a debilitator (Vancouver, Thompson, \& Williams, 2001). Strategies for controlling and reducing emotional arousal (specifically anxiety) while attempting new behaviours should enhance SE beliefs and increase the likelihood of successful implementation (Maddux, 2009). Social integration and regular positive interactions with others are thought to promote better mental and physical health by fostering the development of meaningful social roles, self-worth and SE, and a stable sense of self (Maddux, 2009). According Bandura (2006), the impact that these informational sources have on SE depends on a variety of factors, such as how the individual attends to, interprets, and recalls them.

Results of analysis showed that SE beliefs had influence on their behaviour to work with students with ASD who are included in their classes. Physical educators who had higher levels of selfefficacy toward including students with ASD tended to engage in behaviours associated with inclusion more frequently. In addition, we found that mastery experience, vicarious experience, social persuasion are strong predictors on behaviour. PE teachers who had these experiences performed more often the tasks (modified equipment, activities, instructions, rules, created a safe environment, promoted social interactions, assessed motor skills, collaborated effectively with others, motivated the student) for students with ASD who are included in general physical education classes. Armitage and Conner's (2001) meta-analysis showed that self-efficacy accounted 
for the most additional variance in intention, and both perceived behavioural control and self-efficacy accounted for equivalent proportions of variance in behaviour. The implication is that individuals form intentions that they are confident with and they can enact (those they perceive self-efficacy better), and that translation of intention into action may be facilitated both by self-efficacy and assessment of more external factors tapped by perceived behavioural control (Armitage, \& Conner (2001). Taliaferro (2010) found that PE teachers' SE beliefs toward including a student with ASD were a strong predictor on self-reported inclusion behaviour.

Also SE had a significant inverse relationship with perceived challenges. Physical educators who had higher levels of self-efficacy perceived fewer challenges associated with including students with ASD in their classes. Bandura (1997) proposed that SE beliefs are associated with the degree of challenge that exists in the context of a task. The people who have high levels of SE are more likely to view difficult tasks as a challenge to be overcome rather than avoided, are more likely to put forth more effort and persist longer in these tasks, and are more likely to successfully perform the activity than are people with low SE (Bandura, 1977). As it pertains to teaching students with SEN, physical educators with low self-efficacy may view students with SEN as a threat instead of a challenge for their professional performance (Hutzler et al., 2005). Bandura (1997) suggested that individuals with high levels of SE beliefs are more likely to engage in an activity and more likely to attempt difficult tasks. As a result, those with high SE should perceive fewer challenges, as they feel they have the ability to confront obstacles and succeed if given appropriate effort.

\section{CONCLUSION}

The PESEISD-A-LT instrument' SE scale and subscales appear to be valid and reliable to measure SE of physical educators toward the inclusion of students with ASD in their classes in the context of Lithuania. In this study, positive and significant relationships between SE scale, mastery experience, vicarious experience, social persuasion, physiological state, behavior, and perceived challenges subscales were determined. It may be suggested that the PEISEISD-A-LT version is an appropriate instrument for measuring SE toward including students with ASD frameworks.

\section{REFERENCES}

André, A., Deneuve, P., \& Louvet, B. (2011). Cooperative learning in physical education and acceptance of students with learning disabilities. Journal of Applied Sport Psychology, 23(4), 474-485. https://doi.org/10.10 80/10413200.2011.580826

Armitage, Ch. J., \& Conner, M. (2001). Efficacy of the Theory of Planned Behaviour: A meta-analytic review. British Journal of Social Psychology, 40, 471-499.

Baloun, L., Kudláček, M., Sklenaříková, J., Ješina, O., \& Migdauová, A. (2016). Czech self-efficacy scale for physical education majors towards children with disabilities. Acta Gymnica, 46(1), 44-54. https://doi. org/10.5507/ag.2016.002

Bandura, A. (2006). Adolescent development from an agentic perspective. In F. Pajaresand, T. Urdan (Eds.), Self-efficacy beliefs of adolescents. Greenwich, CT: Information Age Publishing. https://doi.org/10.111 1j.1745-6916.2006.00011.xPMID:26151469

Bandura, A. (1995). Exercise of personal and collective efficacy in changing societies. In A. Bandura (Ed.), Selfefficacy in changing societies (pp. 1-45). New York: Cambridge University Press. https://doi.org/10.10171/ CBO9780511527692
Bandura, A. (1994). Self-efficacy. Encyclopedia of human behavior, 4, 71-81. New York, NY: Academic Press.

Bandura, A. (1997). Self-efficacy: The exercise of control. New York, NY: W. H. Freeman and Company.

Bandura, A. (1977). Self-efficacy: Toward a unifying theory of behavioral change. Psychological Review, 84, 191-215. https://doi.org/10.1037/0033-295X.84.2.191PMID:847061

Bandura, A. (1986). Social foundations of thought and action: A social cognitive theory. Englewood Cliffs, NJ: Prentice-Hall.

Beamer, J. A., \& Yun. J. (2014). Physical educators' beliefs and self-reported behaviors toward including students with autism spectrum disorder. Adapted Physical Activity Quarterly, 31, 362-376. https://doi. org/10.1123/apaq.2014-0134

Block, M. E., Hutzler, Y., Barak, S., \& Klavina, A. (2013). Creation and validation of the situational specific self-efficacy instrument for physical education teacher education majors toward inclusion. Adapted Physical Activity Quarterly, 29, 184-205. https://doi. org/10.1123/apaq.30.2.184 
Block, M. E., Kwon, E. H., \& Healy, S. (2016). Preparing future physical educators for inclusion: changing the physical education teacher training program. Journal of the Brazilian Society for Adapted Motor Activity, 17(1), 9-12. Retrieved from http://www2.marilia.unesp.br/ revistas/index.php/sobama/article/view/6084/4037

Block, M. E., Taliaferro, A., Harris, N., \& Krause, J. (2010). Using Self-Efficacy Theory to facilitate inclusion in general physical education. Journal of Physical Education, Recreation \& Dance, 81(3), 43-46. https:// doi.org/10.1080/07303084.2010.10598448

Booth, T., \& Ainscow, M. (2011). Index for inclusion: Developing learning and participation in schools. Bristol: CSIE. Retrieved from https://www.eenet.org. uk/resources/docs/Index\%20English.pdf

Brislin, R. W. (1986). The wording and translation of research instruments. In J. Lonner and J. W. Berry (Eds.), Field methods in cross-cultural research (pp. 137-164). Newbury, CA: Sage.

Bryman, A. (2015). Social research methods (5th ed.). Oxford, UK: Oxford University Press.

Buns, M. (2010). Environmental support and physical education teacher self-efficacy: A test of Social Cognitive Theory. Graduate Theses and Dissertations. Paper 11832. Retrieved from http://lib.dr.iastate.edu/etd/11832

Campos, M. J. C. (2013). On the way to inclusion: How powerful is physical education? Quantitative and qualitative study about teachers and students' attitudes toward inclusion in Physical Education. Coimbra: [s.n.]. Disponível na WWW. Retrieved from http://hdl.handle. net/10316/24184

Cassady, J. M. (2011). Teachers' attitudes toward the inclusion of students with autism and emotional behavioral disorder. Electronic Journal for Inclusive Education, 2(7), 35-43.

Combs, S., Elliott, S., \& Whipple, K. (2010). Elementary physical education teachers' attitudes towards the inclusion of children with special needs: A qualitative investigation. International Journal of Special Education, 25(1), 115-125. https://files.eric.ed.gov/ fulltext/EJ890572.pdf

Eden, O., \& Hutzler, Y. (2015). Self-efficacy of physical education teachers in teaching students with disabilities in regular classes. In D. Hellerstein-Yehezkel (Ed.), The 20th International Symposium on Adapted Physical Activity: Book of Abstracts (p. 33). Netanya, Israel: The Zinman College of Physical Education and Sport Sciences at the Wingate Institute.

Education Management Information System data. (2018). [2018-08-12]. Retrieved from http:// rsvis.emokykla.lt/cognos8/cgi-bin/cognosisapi.dll?b action $=$ cognos Viewer\&ui.action $=$ run\&ui.object $=02 \overrightarrow{\mathrm{fc}}$ ontent $\% 2$ ffolder $\% 5 \mathrm{~b} \% 40$ name $\% 3 \mathrm{~d} \% 27$ Bendrasis $\% 20$ ugdymas $\% 27 \% 5 \mathrm{~d} \% 2$ ffolder $\% 5 \mathrm{~b} \% 40$ name $\% 3 \mathrm{~d} \% 271$ mokykla $\% 27 \% 5 \mathrm{~d} \% 2$ freport $\% 5 \mathrm{~b} \% 40$ name $\% 3 \mathrm{~d} \% 273 . \% 20$ Speciali $\%$ C 5\%B3j\%C5\%B3\%20ugdymosi $\% 20$ poreiki $\%$ C 5\%B3\%20turintys $\% 20$ mokiniai $\% 20$ bendrojo $\% 20$ ugdymo $\% 20$ mokyk1\%C 5\%B3\%20 bendrosiose $\% 20 \mathrm{klas} \% \mathrm{C} 4 \% 97 \mathrm{se} \% 27 \% 5 \mathrm{~d} \&$ ui.name $=3 . \% 20$
Speciali \%C 5\%B3j\%C5\%B3\%20ugdymosi $\% 20$ poreiki $\% \mathrm{C} 5 \% \mathrm{~B} 3 \% 20$ turintys $\% 20$ mokiniai $\% 20$ bendrojo $\% 20$ ugdymo $\% 20$ mokyk1 $\%$ C5\%B3\%20bendrosiose $\% 20$ klas $\% \mathrm{C} 4 \% 97$ se\&run.outputFormat=\&run.prompt=true\&cv. toolbar=true\&cv.header $=$ false

Field, A. (2009). Discovering Statistics Using SPSS: Introducing Statistical Method (3rd ed.). Thousand Oaks, CA: Sage Publications.

Fisher, Y. (2017). Predicting teachers' perception of inclusion: What is the role of self- efficacy? EC Psychology and Psychiatry, 2(5), 157-171.

Grenier, M., Dyson, B., \& Yeaton, P. (2005). Cooperative learning that includes students with disabilities. Journal of Physical Education, Recreation \& Dance, 76(6), 2935. https://doi.org/10.1080/07303084.2005.10608264

Griggs, G., \& Medcalf, R. (2015). Inclusive pedagogy in physical education. Inclusive Pedagogy across the Curriculum, 7, 119-137. https://doi.org/10.1108/S1479363620150000007013

Heslin, P. A., \& Klehe, U. C. (2006). Self-efficacy. In S. G. Rogelberg (Ed.), Encyclopedia of Industrial/ Organizational Psychology, 2 (pp. 705-708). Thousand Oaks, CA: Sage.

Hodge, S. R., \& Jansma, P. (1999). Effects of contact time and location of practicum experiences on attitudes of physical education majors. Adapted Physical Activity Quarterly, 16, 48-63. https://doi.org/10.1123/ apaq.16.1.48

Humphries, C. A., Hebert, E., Daigle, K., \& Martin, J. (2012). Development of a Physical Education Teaching Efficacy Scale. Measurement in Physical Education and Exercise Science, 16(4), 284-299. https://doi.org/10.108 0/1091367X.2012.716726

Hutzler, Y. (2007). A systematic ecological model for adapting physical activities: Theoretical foundations and practical examples. Adapted Physical Activity Quarterly, 24(4), 287-304. https://doi.org/10.1123/apaq.24.4.287

Hutzler, Y. (2003). Attitudes toward the participation of individuals with disabilities in physical activity: A review. Quest, 55(4), 347-373. https://doi.org/10.1080 /00336297.2003.10491809

Hutzler, Y., \& Barak, S. (2017). Self-efficacy of physical education teachers in including students with cerebral palsy in their classes. Research in Developmental Disabilities, 68, 52-65. https://doi.org/10.1016/j. ridd.2017.07.005

Hutzler, Y., \& Levi, I. (2008). Including children with disability in physical education: General and specific attitudes of high-school students. European Journal of Adapted Physical Activity, 1(2), 21-30.

Hutzler,Y.,Zach,S.,\&Gafni,O.(2005).Physicaleducation student's attitudes and SE towards the participation of children with special needs in regular classes. European Journal of Special Needs Education, 20(3), 309-327. https://doi.org/10.1080/08856250500156038

Ilić-Stošović, D., Nikolić, S., \& Popadić, M. (2015). Teachers' sense of efficacy and implications for implementation of inclusive education. Specijalna 
edukacija i rehabilitacija, 14(3), 345-365. https://doi. org/10.5937/specedreh14-9565.

Jeong, M., \& Block, M. E. (2011). Physical education teachers' beliefs and intentions towards teaching students with disabilities. Research Quarterly for Exercise and Sports, 82(2), 239-246. https://doi.org/10.1080/027013 67.2011.10599751

Jerlinder, K., Danermark, B., \& Gill, P. (2010). Swedish primary-school teachers' attitudes to inclusion: The case of PE and pupils with physical disabilities. European Journal of Special Needs Education, 25(1), 45-57. https://doi.org/10.1080/08856250903450830

Jovanović, L., Kudláček, M., Block, M.E.,\& Djordjević, I. (2014). Self-efficacy of pre-service physical education teachers toward teaching students with disabilities in general physical education classes in Serbia. European Journal of Adapted Physical Activity, 7(2), 32-46.

Karani, K. A., \& Skordilis, E. K. (2016). The intentions of Greek primary education and physical education students to work in an inclusive setting. Academia Journal of Educational Research, 4(1), 8-22. https://doi. org/10.15413/ajer.2015.0131

Karbasi, S., \& Samani, S. (2016). Psychometric properties of Teacher Self-efficacy Scale. ProcediaSocial and Behavior Sciences, 217, 618-621. https://doi. org/10.1016/j.sbspro.2016.02.069

Kiušaitė, J. \& Dubauskaitè, R. (2010). Mokytojų, integruotai ugdančių specialiųų ugdymo poreikių turinčius mokinius, kompetencijos aspektai: socialinis ugdymas: mokslo darbai. Ivairiu visuomenés grupiu socialine integracija, 11(22), 44-54.

Klassen, R. M., \& Tze, V. M. (2014). Teachers' selfefficacy, personality, and teaching effectiveness: A metaanalysis. Educational Research Review, 12, 59-76. https://doi.org/10.1016/j.edurev.2014.06.001

Klavina, A., Jerlinder, K. Kristén, L. Hammar, L., \& Soulie, T. (2014). Cooperative oriented learning in inclusive physical education. European Journal of Special Needs Education, 29(2), 119-134. https://doi.or $\mathrm{g} / 10.1080 / 08856257.2013 .859818$

Ko, B., \& Boswell, B. (2013). Teachers' perceptions, teaching practices, and learning opportunities for inclusion. Physical Educator, 70(3), 223-242.

Kudláček, M., Baloun, L., \& Ješina, O. (2018). The development and validation of revised Inclusive Physical Education Self-Efficacy Questionnaire for Czech physical education majors. International Journal of Inclusive Education. https://oi. org/1080/13603116.2018.1451562

Lent, R. W., \& Hackett, G. (2009). Social Cognitive Theory. In Lopez, S. J. (Ed.) The encyclopedia of positive psychology (pp. 908-912). Malden, MA: Blackwell Publishing. Retrieved from http://simbi.kemenag. go.id/pustaka/images/materibuku/the-encyclopedia-ofpositive-psychology.pdf

Li, C. Wang, L., Block, M. E., Sum, K. W. R., \& Wu, Y. (2018). Validation of the Physical Educators' SelfEfficacy toward Including Students with DisabilitiesAutism for Chinese preservice physical education teachers. Adapted Physical Activity Quarterly, 35(2), 159-174. https://doi.org/10.1123/apaq.2017-0086

Maddux, J. E. (2009). Self-Efficacy. In Lopez, S. J. (Ed.). The encyclopedia of positive psychology (pp. 874-880). Malden, MA: Blackwell Publishing. Retrieved from http://simbi.kemenag.go.id/pustaka/images/materibuku/ the-encyclopedia-of-positive-psychology.pdf

Morgan, J. A. (2013). Factors influencing physical educators' inclusion behaviors towards students with autism spectrum disorder (Doctoral dissertation). Available from Proquest Dissertations and Theses database (UMI No.3574286).

Official Statistics Portal. (2018). Retrieved from https:// osp.stat.gov.lt/statistiniu-rodikliu-analize?theme=all\#/

Parliament of the Republic of Lithuania. (1991). Republic of Lithuania Law on Education, 25 June 1991, No I-1489. Retrieved from https://www.e-tar.lt/portal/lt/ legalAct/TAR.9A3AD08EA5D0/xbPKUCNrMi

Paukštienė, G., \& Ustilaite, S. (2012). Pedagogo specialiujjų kompetencijų ypatumai, ugdant specialiųjų poreikių turinčius vaikus: edukacinès studijos: jaunųjų mokslininkų darbai. Edukologija, 8, 253-263.

Polvi, S., \& Telama, R. (2000). The use of cooperative learning as a social enhancer in physical education. Scandinavian Journal of Educational Research, 44(1), 105-115. https://doi.org/10.1080/713696660

Qi, J., Wang, L. J., \& Ha, A. S. (2016). Perceptions of Hong Kong Physical Education Teachers on the Inclusion of Students with Disabilities. Asia Pacific Journal of Education, 29(2), 1-17. https://doi.org/10.1 080/02188791.2016.1169992

Reina, R., Hemmelmayr, I., \& Sierra-Marroquín, B. (2016). Autoeficacia de Profesores de Educación Física para la Inclusión de Alumnos con Discapacidad y su Relación con la Formación y el Contacto Previo. Psychology, Society \& Education, 8(2), 93-103. https:// doi.org/10.25115/psye.v8i2.455

Sarı, H., Çeliköz, N., \& Seçer, Z. (2009). An analysis of pre-school teachers' and student teachers' attitudes to inclusion and their self-efficacy. International Journal of Special Education, 24(3), 29-44.

Stajkovic, A. D., \& Luthans, F. (1998). Self-efficacy and work-related performance: A meta-analysis. Psychological Bulletin, 124(2), 240-261. https://doi. org/10.1037/0033-2909.124.2.240

Taliaferro, A. R., Hammond, L., \& Wyant, K. (2015). Preservice physical educators' self- efficacy beliefs toward inclusion: The impact of coursework and practicum. Adapted Physical Activity Quarterly, 32, 49-67. https://doi.org/10.1123/apaq.2013-0112

Taliaferro, A., \& Pilkington Harris, H. (2014). The effects of a one-day workshop on physical educators' self-efficacy toward inclusion of students with autism. Palaestra, 28(3), 38-43.

Taliaferro, A., Block, M., Harris, N., \& Krause, J. (2011). Physical educators' self-efficacy toward including students with disabilities - Autism version 8.2 [unpublished survey instrument]. 
Taliaferro, A. (2010). Validation of an instrument to explore physical educators' beliefs toward inclusion: Application of self-efficacy theory: doctoral dissertation. Charlottesville, VA: University of Virginia.

Tant, M. \& Watelain, E. (2016). Forty years later, systematic literature review on inclusion in physical education (1975-2015): A teacher perspective. Educational Research Review, 19, 1-17. https://dx.doi. org/10.1016/j.edurev.2016.04.002

Tekidou, G., Evaggelinou, C., Papaioannou, C., \& Block, M. E. (2015). Self-efficacy of Greek physical education teachers toward inclusion in physical education classes. In D. Hellerstein-Yehezkel (Ed.), The $20^{\text {th }}$ International Symposium on Adapted Physical Activity: Book of Abstracts (p. 90). Netanya, Israel: The Zinman College of Physical Education and Sport Sciences at the Wingate Institute.

Tindall, D., Culhane, M., \& Foley, J. (2016). Pre-service teachers' self-efficacy towards children with disabilities: An Irish perspective. European Journal of Adapted Physical Activity, 9(1), 27-39.

Tschannen-Moran, M., \& McMaster, P. (2009). Sources of self-efficacy: Four professional development formats and their relationship to self-efficacy and implementation of a new teaching strategy. Elementary School Journal, 110(2), 228-245. https://dx.doi.org/10.1086/605771

Tschannen-Moran, M., Woolfolk Hoy, A., \& Hoy, W. K. (1998). Teacher efficacy: Its meaning and measure. Review of Educational Research, 68, 202-248. https:// doi.org/10.3102/00346543068002202
Tschannen-Moran, M., \& Woolfolk Hoy, A. (2001). Teacher efficacy: Capturing an elusive construct. teaching and teacher education, 17, 783-805. https:// doi.org/10.1016/S0742-051X(01)00036-1

Tschannen-Moran, M., \& Woolfolk Hoy, A. (2007). The differential antecedents of self-efficacy beliefs of novice and experienced teachers. Teaching and Teacher Education, 236, 944-956. https://doi.org/10.1016/j. tate.2006.05.003

Tubić, T., \& Đorđić, V. (2012). Inclusive physical education in Vojvodina: The current situation and future prospects. Facta Universitatiss: Physical Education and Sport, 10(4), 319-327.

Vallerand, R. J. (1989). Vers une méthodologie de validation trans-culturelle de questionnaires psychologiques: Implications pour la recherche en langue française. Canadian Psychology / Psychologie Canadienne, 30(4), 662-680. https://doi.org/10.1037/ h0079856

Vancouver, J. B., Thompson, C. M., \& Williams, A. A. (2001). The changing signs in the relationships among self-efficacy, personal goals, and performance. Journal of Applied Psychology, 86(4), 605-620. https://doi. org/10.1037//0021-9010.86.4.605

Yada, A., \& Savolainen, H. (2017). Japanese in-service teachers' attitudes toward inclusive education and selfefficacy for inclusive practices. Teaching and Teacher Education, 64, 222-229. https://doi.org/10.1016/j. tate.2017.02.005
Corresponding author Dovilè Selickaitė Department of Applied Biology and Rehabilitation Lithuanian Sports University Sporto str. 6, LT-44221 Kaunas Lithuania

E-mail dovile.selickaite@gmail.com 